\title{
Is the Non-Justiciability of Economic and Socio-Cultural Rights in the Nigerian constitution Unassailable? Re-Examining Judicial Bypass from the Lens of South African and Indian Experiences
}

\author{
Hemen Philip Faga ${ }^{1}$, Francis Aloh ${ }^{2}$, Uchechukwu Uguru ${ }^{3}$ \\ ${ }^{1}$ Faculty of Law, Ebonyi State University, Nigeria, Email: hemenfaga@gmail.com \\ 2 9-mobile Telecommunications Limited,Nigeria,Email:aloh_francis@yahoo.com \\ ${ }^{3}$ Faculty of Law, Ebonyi State University, Nigeria, Email: uguruche@yahoo.com
}

\section{Article Info}

Abstract

\begin{tabular}{|c|c|}
\hline $\begin{array}{l}\text { Keywords: } \\
\text { Justiciability, Economic, Social } \\
\text { and Cultural Rights. }\end{array}$ & $\begin{array}{l}\text { The } 1999 \text { Constitution of the Federal Republic of } \\
\text { Nigeria, as amended (CFRN) recognizes the } \\
\text { entitlement of every Nigerian within its borders to } \\
\text { enjoy economic and socio-cultural (ESC) rights }\end{array}$ \\
\hline How to cite: & under Fundamental Objectives and Directive \\
\hline $\begin{array}{l}\text { Philip Faga, Francis Aloh, } \\
\text { ukwu Uguru, "Is the Non- }\end{array}$ & $\begin{array}{l}\text { Principles of State Policy. However, the } \\
\text { constitution seemingly renders these ESC rights }\end{array}$ \\
\hline Justic & non-justiciable or unenforceable. This paper \\
\hline Socic & $\begin{array}{l}\text { examines the efforts of the Nigerian judiciary to } \\
\text { bypass the non-Justiciability provision to enforce }\end{array}$ \\
\hline $\begin{array}{l}\text { Nige } \\
\text { Unas }\end{array}$ & ESC rights in Nigeria. It mainly investigates the \\
\hline Judi & role \\
\hline South & \\
\hline ences, " Fiat Justisia 14, 3 & $\begin{array}{l}\text { ence of the enforcement of } \\
\text { Therefore, the paper adopts } \\
\text { d and recommends that both }\end{array}$ \\
\hline & and the judiciary should \\
\hline 10. & of ESC righ \\
\hline
\end{tabular}

\section{A. Introduction}

The introduction of human rights into Nigeria's jurisprudence dates back to independence in $1960,{ }^{1}$ but the Economic, Social and Cultural (ESC) rights were included subsequently in the 1979 Constitution. ${ }^{2}$ The

\footnotetext{
${ }^{1}$ Nigeria has over 250 ethnic groups with only three of them dominant. Hence, to allay fears of subjugation by the majority, a commission was inaugurated and chaired by Sir Henry Willink, a colonial officer, and its report better known as the Willink Commission Report [1959], was turned in at the eve of Nigeria's independence recommending the insertion of human rights into the 1960 Constitution.

${ }^{2}$ See Chapter II of the 1979 Constitution of the Federal Republic of Nigeria.
} 
legal effect given to both categories of rights at the time was not dependent on social considerations, judicial complexities or Justiciability; instead, it was dependent on two considerations of convenient political ideology and economic situation of the country. ${ }^{3}$ Moreover, the United Nations at different times adopted the Civil and Political Rights and Economic, Social and Cultural Rights as international covenants and both rights were jointly given equal recognition irrespective of divergencies of preference between the East and the West. ${ }^{4}$ Unfortunately, the Nigerian Constitution Drafting Committee ("CDC") at the time favoured rendering Fundamental Human Rights ("FH rights") justiciable chiefly because they were deemed selfexecuting rights and imposed little or no positive duties on the government; $;$. In contrast, ESC rights are 'programmatic' ${ }^{\prime 6}$ positive rights that would require the government to take deliberate steps to ensure the enjoyment of the rights. Hence, the CDC had opined as follows:

All fundamental rights are, in the final analysis, rights which impose limitations on executive government and are accordingly easily justiciable. By contrast, economic and social rights are different. They do not impose any restrictions on governmental powers. They impose obligations of a kind, which are not justiciable. To insist that the right to freedom of expression is the same kind of 'right' as the right to free medical facilities and can be treated alike in a constitutional document is unsound. ${ }^{7}$

One may concede, momentarily though, that at the point the various Nigerian constitutions ${ }^{8}$ were drafted, there were instabilities in the polity, which affected the whole spectrum of governance, including legislative and judicial functions, and the economy. Also, much of Nigerian laws, practices and customs were by default adopted and copied ipsissima verba from the West. Nonetheless, the above statement of the CDC justifying the

\footnotetext{
${ }^{3}$ The East and the West had ideological differences, sometimes deemed rivalry, at the point the International Bill of rights. See M. Craven, The International Covenant on Economic, Social and Cultural Rights: A perspective on its Development (Oxford: Clarendon Press, 1995). It is also true that many ESC rights are enforceable or justiciable in the East while the West favours political and civil rights.

4 Allan Mc Chesney,Promotion, defending Economic, Social and Cultural Rights: A Handbook (Washington DC: American Association for the Advancement of Science, USA, 2000), available at: https://www.huridocs.org/wp-content/uploads/2010/08/ESCRhandbookeng.pdf (retrieved 11 August 2019).

5 That is, the right does not require government to do anything whatsoever but in some instance admonishes the government to desist from doing acts that frustrates the enjoyment of the rights. However, under Section 44 of the 1999 Constitution of the Federal Republic of Nigeria, as amended, the government can act contrary to these rights on the ground of public policy, public safety.

${ }^{6}$ Henry J. Steiner \& Philip Alston, International Human Rights in Context: Law, Politics, and Morals (Oxford. Fourth Cluster Reader, ERMA, 2003), 245.

${ }^{7}$ M. Craven, Loc.Cit.

${ }^{8}$ 1960, 1965, 1979, 1995 and 1999 Constitutions of the Federal Republic of Nigeria.
} 
inclusion of ESC rights in the constitution as non-justiciable obligations of government is untenable because many countries especially in the East, have easily adopted the ESC covenants as enforceable rights ahead of FH rights covenants. ${ }^{9}$

Justiciability is used here implies the enablement of a citizen to demand from the executive and the legislature, the performance of ESC rights and access to the court to determine the propriety of actions or inactions of the executive and legislature, which impact negatively on the citizens' ability to enjoy the ESC rights. For FH rights, it is not seriously contested that they are enforceable; ${ }^{10}$ however, both the Hand ESC rights are interdependent, and it is therefore nearly impossible to enjoy one without the other. ${ }^{11}$ As Jordan explained:

Furthermore, human society's basic principles such as freedom, justice and peace cannot exist without inalienable human rights of all the members of the human family, 'because the ideal of free human beings enjoying freedom from fear and want can only be achieved if conditions are created whereby everyone may enjoy' his economic, social and cultural rights, as well as his civil and political rights and freedom. ${ }^{12}$

ESC rights cannot be considered as mere political principles ${ }^{13}$ postponed to an indefinite future date and bereft of Justiciability because this masks the failure of government to perform its obligations to the citizens. ${ }^{14}$ According to Igwe, ${ }^{15}$

${ }^{9}$ Certain European, South American, Asian and Arabian Countries even certain African Countries have provisions in their constitutions rendering ESC rights justiciable and the observance has been sustained over the years without the economies of the said countries crumbling.

${ }^{10}$ General Comment No.9 "Substantive Issues Arising in the Implementation of the International Covenant on Economic, Social and Cultural Rights" Committee on Economic, Social and Cultural Rights. E/C.12/1998/24, par.10.

${ }^{11}$ How can somebody who needs food, water, house, or without education, be expected to fully exercise his civil and political rights such as the right to vote, or the right to freedom of association? Indeed, none can exercise his political rights fully without the enjoyment of ESCR. The same goes also for ESCR; they cannot be protected and enjoined without enjoying CPR. In addition, this idea became more accepted as ESCR include a major concern over the protection of vulnerable groups, such as the poor, the handicapped and indigenous people. See Fons Coomans, Fried Van Hoof, Kitty Arambulo, Jacqueline Smith and Brigit Toebes, The Right to Complain about Economic, Social and Cultural Rights (Utrecht: Netherlands Institute for Human Rights, 1995), 2.

12 Daci Jordan, "Justiciability of Economic, Social and Cultural Rights", Academicus International Scientific Journal 9, (2014): 54-67, https://doi.org/10.7336/academicus.2014.09.04.

13 Asbjorn EIDE, Catarina Krause and Allan Rosas (eds.), Economic, Social, and Cultural Rights (Kluwer: Martin Nijhoff Publishers, 1995), 17-19.

${ }^{14}$ In the case of Nigeria-International Covenant on Economic, Social and Cultural Rights; African Charter on Human and Peoples Rights; African Charter on Human and People's Rights (Ratification and Enforcement) Act, Cap A9 LFN 2004; Child Rights Act (CRA). 
When viewed properly, the concept of interdependence of human rights, assures that without proactive measures by the state to guarantee universal access to essential services and resources (including education, food, water and healthcare), civil and political rights will not make any meaning. Also, without civil and political rights (such as freedom of speech, right to assembly and administrative justice), citizens will be denied the ability to participate as active agents in the realization of their social and economic needs.

Hence, the 'guarantee of ESC rights is essential to democracy to ensure 'minimum equality of access to civil and political rights' ${ }^{16}$ for the citizenry. Unfortunately, while Chapter II of the Nigeria constitution 1999 (as amended) included ESC rights, section 6 (6) (c) of the constitution renders them unenforceable. This paper examines the nature of the nonJusticiability provision of the constitution to ascertain the possibility of both the legislature and judiciary to circumvent it and enforce ESC rights in Nigeria.

This paper utilizes the qualitative doctrinal method to investigate the problem of non-Justiciability of ESC right litigation in Nigeria. However, due to the paucity of internal judicial and statutory legal norms to reconcile the constitutional limitation of unenforceability with the various mechanisms of enforcement of ESC rights in other jurisdictions, the paper adopts the comparative method using the South African and Indian experiences to extrapolate as to the prospects of Esc right enforcement in Nigeria.

\section{B. Discussion}

\section{The Gist of Nigeria's Economic, Social and Cultural Rights}

There are four major sources of ESC rights in Nigeria: the Constitution of the Federal Republic of Nigeria 1999 (CFRN); the African Charter on Human and Peoples Rights (Ratification and Enforcement) Act ('African Charter'); ${ }^{17}$ the Child Rights Act 2003 (CRA); $;{ }^{18}$ and the Compulsory, Free Universal Basic Education Act (UBE). ${ }^{19}$ Although the CFRN is the primus interpares amongst the four, the African Charter and the CRA having been

\footnotetext{
${ }^{15}$ O. W. Igwe, "A Legal Assessment of the Positive Duties Imposed by Economic, Social and Cultural Rights in Nigeria", American International Journal of Social Science 3, 4 (2014).

${ }^{16}$ David Beetham, Democracy and Human Rights (USA: Blackwell Publisher Ltd. Malden, 2000), 98.

${ }^{17}$ Domestication of the African Charter on Human and Peoples Rights.

${ }^{18}$ This Act domesticated the United Nations Convention on the Rights of a Child.

19 Federal Republic of Nigeria 2004, Official Gazette, 91 (66), Govt. Notice No. 142, Lagos, Nigeria: Federal Government Press.
} 
domesticated ${ }^{20}$ has the full force of law in Nigeria, and its provisions are justiciable and enforceable through the Nigerian Courts. However, the CFRN being the grund norm renders void the provisions of any other extant law in Nigeria that is inconsistent it $;{ }^{21}$ hence the judicial uncertainty and outright refusal of the courts to entertain ESC rights claims as contained in the African Charter, CRA and UBE.

The clear intentions of the CFRN to have ESC rights enjoyed by the citizens is manifest in the provisions of sections 15-20, which enjoins government to make policy towards suitable and adequate shelter and food, reasonable national minimum wage, old age care and pension, sick benefits and welfare of citizens; adequate medical and health facilities; free, (compulsory) and universal education; and protection of the environment. However, the CFRN, which labelled these rights as Fundamental Objectives and Directive Principles of State Policy, rendered them nonjusticiable by ousting the jurisdiction of the court to entertain or enquire into their performance or non-performance. Section 6(6) (c) of CFRN provides that judicial powers:

Shall not except as otherwise provided by this Constitution, extend to any issue or question as to whether any act or omission by any authority or person or as to whether any law or any judicial decision is in conformity with the Fundamental Objectives and Directive Principles of State Policy set out in Chapter II of this Constitution.

Having noted the qualifying provision of the CFRN on ESC rights contained therein, what are then the legal implications of the state enacting the African Charter, CRA and UBE, which rendered certain ESC rights justiciable? Do the justiciable provisions of these latter laws conflict with the CFRN as to render them void or does it complement the CFRN to the extent that they signify the intention of the state to now render justiciable and provide absolute legal force for the enforceability of ESC rights? These questions prod our mind, when Section 6 (6) (c) set out above, is juxtaposed with Section 13 of the CFRN which provides that:

It shall be the duty and responsibility of all organs of government, and of all authorities and persons, exercising legislative, executive or judicial powers, to conform to, observe and apply the provisions of this Chapter of this Constitution.

A combined reading of sections 6 (6) (c) and 13 of the CFRN seems to create conflicting interpretations, notwithstanding that the Nigerian courts

\footnotetext{
20 The African Charter and the CRA have been enacted as Nigerian law as required by Section 12 (1) of the CFRN which provides that "no treaty between the Federation and any other country shall have the force of law except to the extent to which such treaty has been enacted into law by the National Assembly".

${ }^{21}$ Chief Gani Fawehinmi v. Sani Abacha (2000) NWLR (Pt. 660) 228 and section 1 (3) of the CFRN.
} 
have placed heavy reliance on section 6 (6) (c) alone because it refers expressly to the court in determining issues arising from the provisions of the CFRN. However, if the courts were to review these provisions together and because of the express Justiciability provisions of the African Charter and CRA-we believe it would come to a different conclusion as to the Justiciability of the affected ESC rights.

\section{Misconception about the Adjudication of ESC Rights in Nigeria}

The general notion seems to be that Nigerian Courts appear to have taken a conservative and restrictive approach to cases relating to the ESC rights provisions of Chapter II of the CFRN as well as ESC provisions in other statutes. This misconception is hinged on two narrow construction of the CFRN as ousting the jurisdiction of the courts from inquiring into whether authority or person has performed or breached the ESC rights provisions of the CFRN; and that irrespective of the provisions of any subsequent law, the court is still bound to rescues itself from ESC rights related claims. We will now dissect these misconceptions from the decisions of Nigerian courts in various ESC related litigations as well as the dictums or rationales put forward by the justices of the courts in reaching the decisions.

As stated above, ESC rights are provided in varying specifics, in the CFRN, the African Charter, the CRA and the UBE. The CFRN contains much detailed ESC provisions cutting across health and health facilities, education at various levels, equal pay for equal work, sane and safe environment, public assistance and adult literacy. The African Charter, on the other hand, mainly provides for two ESC rights: the right to the best state of 'physical and mental health,' and right to 'education'. The UBE on its part mandates the different tiers of government in Nigeria to provide free, compulsory, and universal primary education. ${ }^{22}$ It is correct to state that in the ranking of laws, the CFRN stands taller and takes precedence over every other law in Nigeria, including the African Charter, CRA and UBE. ${ }^{23}$ This notwithstanding, can the ESC provisions of the African Charter, CRA and UBE be invoked on their standing as extant laws with the full force of law ${ }^{24}$-without recourse to CFRN or does the CFRN restrict the legislature and the executive from enacting laws to render justiciable any of the ESC rights contained in the CFRN?. If the response is in the negative, then it will be difficult to rationalize the misconceptions and long-standing position of some courts in Nigerian on non-Justiciability of ESC rights, especially in relation to the obligations of government.

\footnotetext{
${ }^{22}$ Section 2(1).

${ }^{23}$ Fawehinmi v. Abacha (2000) NWLR [Pt. 660] 228.

${ }^{24}$ Ogugu v. State, (1996) 6 NWLR [Pt. 316] 1, 30-31. With particular reference to the African Charter.
} 
The section $6(6)(\mathrm{c})$ of the CFRN states that the adjudicatory powers of the court shall not extend to the performance or conformity by any person or authority with the provisions on Fundamental Objectives and Directive Principles of State Policy in Chapter II of the CFRN. Note that the ouster relates strictly to the ESC provisions in the CFRN and does not seem to refer to any other law that was or is enacted in relation to ESC rights in Nigeria. The earliest opportunity the court had to interpret the nonJusticiability provision of the CFRN was in Archbishop Anthony Okogiev. A.G. Lagos State ${ }^{25}$ (Okogie's Case) wherein the Nigerian Court of Appeal held that:

While Section 13 makes it a duty and responsibility of the judiciary among other organs of government, to conform to and apply the provisions of Chapter II, Section 6(6) (c) of the same Constitution makes it clear that no court has jurisdiction to pronounce any decision as to whether any organ of government has acted or is acting in conformity with the Fundamental Objectives and Directive Principles. It is clear that section 13 has not made Chapter II justiciable.

This singular decision of the court remains the flagship for the nonJusticiability sermon, which prohibits Nigerian Courts from entertaining ESC rights litigation in Nigeria. Indeed, the decision continues to fuel even more sinister misconceptions about ESC adjudication in Nigeria. ${ }^{26}$ Proponents of the non-Justiciability of ESC rights argue that the courts do not have the facilities to deal with the issue of resource allocation and budgeting required in the implementation of ESC rights, which is the function of the legislature and the executive. ${ }^{27}$ The courts also do not represent the communal choice of the citizenry brought into office by electoral processes. More so, such an exercise by the court blurs the lines of separation of powers.

Hence, the court in Okogie's case recued itself from ESC right litigation thereby raising certain issues; first, whether section 6 (6)(c) does indeed forbid the courts from entertaining cases touching on ESC rights and by extension whether claiming such rights based on provisions in other legislations amount to inconsistency with the CFRN. Second, whether section 6 (6) (c) removes the authority of the legislature to make laws creating socio-economic rights like those contained in Chapter II of the

\footnotetext{
${ }^{25} 2$ NCLR 337 (1981) at 350.

${ }^{26}$ Solomon T. Ebobrah, "The Future of Economic, Social and Cultural Rights Litigation in Nigeria", CALS, Review of Nigeria Law and Practice 1, No. 2 (2007), 108.

27 Lord Lester of Herne Hill QC \& ColmO'Cinneide, The Effective Protection of Socioeconomic Rights, in Y. Ghai and J. Cottrell (eds.), Economic, Social and Cultural Rights in Practice: The Role of Judges in Implementing Economic, Social and Cultural Rights, London: Interights, (2004).
} 
CFRN. ${ }^{28}$ Regarding the first issue, the African Charter mirrors the African Union Protocol to the African Charter on Human and Peoples' Rights, which was adopted and domesticated as a Nigerian law pursuant to Section 12 of the CFRN. Although Nigeria's Supreme Court has held that the provisions of the African Charter can be enforced using the regular rules of court, ${ }^{29}$ the court held in another case that between the CFRN and the African Charter, any inconsistency or conflict should be resolved in favour of the CFRN. ${ }^{30}$ Both Obiagwu and Odinkalu ${ }^{31}$ and Igwe ${ }^{32}$ suggests that to hold the view that the African Charter 'cannot introduce justiciable rights, which the CFRN has declared non-justiciable', invariably suggests that the provisions of the African Charter conflicts with that of the CFRN.

We disagree with this reasoning because there is no argument that the CFRN only renders non-justiciable the provisions of Chapter II of the CFRN; there is no express or implied intention in the CFRN to extend the limitation of the enforcement of ESC rights beyond the constitution. The provisions of Part support this position I of the Second Schedule, Item 60 (a) of the CFRN, which empowers the legislature to make laws towards the establishment and regulation of bodies to see to the enforcement of the provisions of Chapter II of the CFRN. It is based on this provision that the Nigerian legislature has enacted various legislations to give vent to specific provisions of Chapter II of the constitution such as the Independent Corrupt Practices Commission (ICPC) Act 2000, enacted to eliminate corruption under section 15 (5) of the CFRN and the African Charter (Ratification and Enforcement) Act 1983. Other legislations include the National Environmental Standards Regulatory and Enforcement Agency (NESREA) Act 2007 enacted to fulfil the objective of environmental protection under section 20 of the CFRN, the Universal Basic Education Act, and the National Agency for the Prohibition of Trafficking in Persons Act 2003, enacted to fulfil various provisions in Chapter II of the CFRN. In the case of A.G. Lagos State v. A.G. Federation, ${ }^{33}$ the Nigerian Supreme Court held that the National Assembly acted within its constitutional

\footnotetext{
${ }^{28}$ Ebobrah, above, note 26, 108.

${ }^{29}$ Ogugu v. State, (1996) 6 NWLR [Pt. 316] 1, 30-31.

${ }^{30}$ Chief Gani Fawehinmi v. Sani Abacha (2000) NWLR [Pt. 660] 228.

31 Chinonye Obiagwu \& Chidi Anselm Odinkalu, Nigeria: Combating Legacies of Colonialism and Militarism, In Abdullahi An-Na'im (ed.), Human Rights under African Constitutions: Realizing the Promise for Ourselves (Philadelphia: University of Pennsylvania Press, 2003), 227. However, they further opined that the African Charter being a statute by itself, is capable of enforcement notwithstanding the ouster provisions of the CFRN.

32 O.W. Igwe, "A Legal Assessment of the Positive Duties Imposed by Economic, Social and Cultural Rights in Nigeria", American International Journal of Social Science 3, No. 4 (2014).

${ }^{33} 15$ NWLR [Pt. 842] 113 (2003), 175.
} 
powers under Section 20 of the CFRN (also in Chapter II) when it enacted the Federal Environmental Protection Agency Act (now NESREA Act). Concerning the ICPC Act, the Supreme Court also held: ${ }^{34}$

Courts cannot enforce any of the provisions of Chapter 2 of the Constitution until the National Assembly has enacted specific laws for their enforcement, as has been done in respect of section 15(5) of the 1999 Constitution by the enactment of the Corrupt Practices and Other Related Offences Act, 2000... But the Directive Principles...can be made justiciable by legislation.

This decision clearly emphasizes that notwithstanding section 6(6) (c) of the CFRN, Chapter II of the constitution can be made justiciable by legislation. Furthermore, the Supreme Court, in the case of Federal Republic of Nigeria v. Alhaji Mika Anache \& Others $^{35}$ reasoned that:

The non-Justiciability of section 6(6) (c) of the Constitution is neither total nor sacrosanct as the subsection provides a leeway by the use of the words 'except as otherwise provided by this Constitution'. This means that if the Constitution otherwise provides in another section, which makes a section or sections of Chapter II justiciable, it will be so interpreted by the courts.

Therefore, that the provisions of the African Charter Act, the Child's Rights Act and the Universal Basic Education Act can be invoked to demand from the government and any other authority or private individuals the respect, protection and fulfilment or performance of the ESC rights contained therein, this adequately answers the two issues raised above and brings us to the point of enquiry regarding why there is a dearth of ESC rights litigation and consequent enforcement orders from Nigerian Courts using the instrumentality of these laws. Could it be a system defect in the judicial process in Nigeria or a statutory impediment in the enforcement of orders against the government, its ministries, departments and agencies (MDA) that account for this paucity of ESC litigation in Nigeria? ? $^{36}$

\section{The Legislation and Attitude of the Judiciary in the Enforcement of ESC Rights in South Africa and India}

We will now explore the creative approach of the courts and litigants in other jurisdictions, with similar ouster clause provisions in their constitution such as South Africa and India. The study intends to argue that

\footnotetext{
${ }^{34} A G$ of Ondo State v. AG Federation (2002) 9 NWLR, [Pt. 772], at 272.

${ }^{35} 14$ WRN (2004) 1-90 61.

${ }^{36}$ Sections 84(1-3) Sheriffs and Civil Process Act, Cap. 407, Laws of the Federation, 1990 which requires that before an order of court against the assets in the custody of a public officer in his official capacity, such as money or other property belong to the government, the consent of the Attorney-General at the federal or state level, depending on the government agency, must be obtained before such order can be enforced.
} 
the approaches utilized in these countries could equally be applied in Nigeria by the courts and litigants and that this could achieve the same results.

\section{a. South Africa}

The Constitution of the Republic of South Africa 1996 (SA Constitution), is the supreme law in South Africa. All other laws and policies of government derive from it, as it provides for the structure of government, the interaction between the arms of government, taxation, resource allocation as well as regulation of the role of government and nonstarter actors in realizing constitutionally provided rights. ${ }^{37}$ Section 2 of the SA Constitution, like section 1(3) of the CFRN, preserves its supremacy by clearly stating that any law or conduct that is inconsistent with the SA Constitution is invalid, whether an act or omission. Constitutional obligations 'must be fulfilled'. ${ }^{38}$ The SA Constitution makes provision for various ESC rights including health services, access to housing, food and water, public assistance amongst others. ${ }^{39}$ The striking point to note with the SA Constitution is that ESC rights provided therein involve a mix of 'negative and positive obligations' regarding do have and don'ts the government has to observe in relation to ESC rights. More so, the SA courts have held that ESC rights are intertwined or interdependent with civil and political rights. ${ }^{40}$ In the words of the court:

Our Constitution entrenches both civil and political rights and social and economic rights. All the rights in our Bill of Rights are interrelated and mutually supporting.

With this understanding, the SA courts would appear to have a better constitutional mechanism to handle ESC related claims. However, no section of the SA constitution expressly renders the ESC provisions

\footnotetext{
37 For detail on the role of the Constitution in regulating the development and implementation of health law and policy, see generally VarunGauri and Daniel M. Brinks (eds.), Courting Social Justice: Judicial Enforcement of Social and Economic Rights in the Developing World (Cambridge University Press, 2008).

${ }^{38}$ Jonathan Berger, Litigation for Social Justice in Post-Apartheid South Africa: A Focus on Health and Education, in Varun Gauri and Daniel M. Brinks (eds.), Ibid (Chapter 2), 38-96.

39 These rights include access to land (Section 25, which also deals more broadly with property rights); access to housing, which expressly includes protection against unjustifiable and arbitrary evictions (Section 26); access to health care services (including reproductive health care) and a guarantee that "no one may be refused emergency medical treatment" (Section 27); access to sufficient food and water (Section 27); access to social security, including "appropriate social assistance" where people are "unable to support themselves and their dependents" (Section 27); and "basic education, including adult basic education" (Section 29). In addition, ESC rights are to be found in Sections 23 (fair labor practices), 24 (environment), 28 (children), and 35 (prisoners).

${ }^{40}$ Government of Republic of South Africa v Irene Grootboom and Others 2001 (1) SA 46

(CC) para.2 (S. Afr.) [here in after Grootboom].
} 
justiciable or otherwise. Nonetheless, SA courts have adopted the strategic declarations in ESC related litigations that ensure that its orders are complied with. The SA court takes cognizance of its broad constitutional powers to grant 'appropriate relief' 41 and wields discretion to make 'any order that is just and equitable'. ${ }^{42}$ The SA court in Fose v. Minister of Safety and Security ${ }^{43}$ interpreted the appropriate relief to mean such 'relief that is required to protect and enforce the constitution and the court may even fashion new remedies to secure the protection and enforcement of allimportant rights'. ${ }^{44}$

Some of the enforcement measures adopted by the SA courts include an extension of constitutional provisions through reading certain words into an arrangement to extend the benefits, ${ }^{45}$ and an order requiring rectifying its breach of the constitutional provision under the supervision of the court ${ }^{46}$ government or under the supervision of statutory bodies. ${ }^{47}$ Furthermore, although section 3 of the SA State Liability Act ${ }^{48}$ precludes a successful litigant from executing a final court judgment against the assets of the state or that of its officials, there could be the incidence of court order coercing public official into compliance with court orders.

\section{b. India}

The Indian Constitution ${ }^{49}$ differentiates justiciable fundamental rights, which the government or any other citizen must not contravene, and nonjusticiable ESC provisions couched similarly to the Nigerian constitution under the Directive Principles, which are mere aspirations and political statements. Article 37 of the Indian Constitution states that the provisions of the Directive Principles "shall not be enforceable by any court, but the principles therein laid down are nevertheless fundamental in the governance of the country, and it shall be the duty of the state to apply these principles in making laws". Interestingly, the Indian Courts adopted a means to give impetus to the provisions of Part IV of its Constitution.

\footnotetext{
${ }^{41}$ Section 38 of SA Constitution.

42 Ibid., Section 172 (1) (b).see generally, Eric C. Christiansen, "Adjudicating NonJusticiable Rights: Socio-Economic Rights and the South African Constitutional Court", 38 Columbia Human Rights L. Rev 321, (2007): 347-384.

431997 (3) SA 786 (CC) at Paragraph 19.

${ }^{44}$ Ibid., 39.

${ }^{45}$ National Coalition for Gay and Lesbian Equality v. Minister of Home Affairs 2000 (2) SA 1 (CC).

${ }^{46}$ August v. Electoral Commission 1999 (3) SA 1 (CC).

${ }^{47}$ Vumazonke v.Member of the Executive Council for Social Development, Eastern Cape Province, unreported decision of the Port Elizabeth High Court in Case No. 2004/050 (25 November 2004).

48 No. 20 of 1957.

49 The Constitution of India, 1950. Part IV, Articles 36-50 for ESC rights.
} 
Indian courts are reputed for activism in protecting and beneficially interpreting the provisions of the Indian Constitution. Thus, in this way the Indian Courts have transformed the ESC rights of primary education, health, food, shelter, anti-child labour and equal wages for equal work from non-justiciable under the Indian Constitution into legally enforceable rights. In the case of Unnikrishnan $v$. State of $A P^{50}$ an Indian court held that irrespective of the designation of a right, it could be treated as fundamental notwithstanding that it is not provided for in the fundamental rights section of the Indian Constitution. In yet another case, the Indian Supreme Court interpreted the right to health, a non-justiciable right, to form part of the fundamental right to life. ${ }^{51}$ The dynamic interpretative activism of Indian courts stems from the holding of the Indian Supreme Court in one of the earliest ESC rights cases seeking to settle supremacy between fundamental rights provisions and ESC rights provisions of the Indian Constitution. ${ }^{52}$ It was resolved that neither should be superior as "what is fundamental in the governance of a country cannot be less significant than what is significant in the life of the individual'. ${ }^{53}$ Although Indian courts have not always come to the rescue of litigants suing under the ESC right provisions, they have not failed to strike down any legislation that infringes on ESC rights provisions in the constitution. ${ }^{54}$

To ensure compliance with their decisions with respect to suits against the government, Indian courts would make either a finding or a declaration for the right claimed without granting a remedy or order the government to develop a plan, usually within a specific period to cure the said violation of ESC right. Like SA courts, the Indian court also supervises the implementation of its orders directly by both monitoring the implementation of the orders and giving the petitioner opportunity to request for new directions, or indirectly by appointing supervising authority. The challenge with this system of enforcement is that although the declaration of right is made, it sometimes remains unenforced, as the government would resort to budgetary constraint as an excuse. Yet, the ESC rights have been accorded Justiciability and would, in a matter of time be enforced. ${ }^{55}$

\footnotetext{
${ }^{50} 1$ SCC 645 (1993).

${ }^{51}$ Francis Coralie Mullin v The Administrator, Union Territory of Delhi (1981) 2 SCR 516.

52 V.R. Krishna Iyer, J. in State of Kerala v. N. M. Thomas (1976) 2 SCC 310 at para.134, p.367.

${ }^{53}$ Circle of Rights, "Justiciability of ESC Rights - the Indian Experience" University of Minnesota, Human Rights Resource Centre, available at:http://hrlibrary.umn.edu/edumat/IHRIP/circle/justiciability.htm (retrieved 21 August 2019).

${ }^{54}$ Central Inland Water Transp. Corp. v. Ganguly (1986) 2 S.C.R. 385-88.

55 Se generally, Ajah Damian Uche, "Comparative Appraisal of the Protection and Enforcement of Economic, Social and Cultural Rights Under the Law in South Africa, India
} 
As both the South African and Indian approaches reveal, the extent to which ESC right provisions in Chapter II of the CFRN will be actualized dependent on the ability of the Nigerian judiciary to adopt mechanisms that give priority to their actualization above the ouster provisions of the constitution. Such judicial activism directly reveals the viability and resourcefulness of a country's judicial system. ${ }^{56}$

\section{Judicial Bypass of Non-Justiciability Provisions and Enforcement of ESC Rights in Nigeria}

Many writers argue that the major impediment to ESC rights adjudication in Nigeria lies in the 'subject to consent 'requirement in the enforcement of judgments of court against the government or its agencies. ${ }^{57}$ Until now, the government has not granted its approval to the enforcement of any ESC decision against it that is known to us. Thus, it is not difficult to see the apathy of prospective litigants in even attempting to sue the government to enforce their ESC rights in Nigeria. Beyond this hurdle, the court has to still deal with the legalism of non-Justiciability of ESC rights provided in section 6 (6) (c) of the CFRN 1999.

The summary of the adjudicatory and enforcement practices of South African and Indian courts is that (1) ESC rights are often litigated as a subset of FH rights; (2) government and its agencies are often coerced to comply with court judgments through structural court supervision of implementation; and (3) declaration as void government programs, legislation and policies that infringe on ESC rights. In India, judicial activism gained expression through clothing non-justiciable provisions of the Indian Constitution with enforceability through the close linked FH right. ${ }^{58}$ And it has been argued similarly in Nigeria situation that where an ESC right being claimed can be related to an FH right or has been legislated upon. There is a probable presumption that any 'infringing executive action will be held unconstitutional' ${ }^{59}$

There are reported instances of Nigerian courts indirectly according to Justiciability to ESC rights through an extended interpretation of FH right

and Nigeria”, Unpublished LL.M Dissertation, Faculty of Law, University of Nigeria, Enugu, (2013): 110-141.

${ }^{56}$ International Commission of Jurists, Courts and the Legal Enforcement of Economic, Social and Cultural Rights: Comparative Experiences of Justiciability (Geneva: International Commission of Jurists, 2008), 65-72.

${ }^{57}$ Sections 84 and 85 of the Sheriff and Civil Processes Act, LFN 2004.

${ }^{58}$ See International Commission of Jurists, Op.Cit.,73-88.

${ }^{59}$ Atudiwe P. Atupare, "Reconciling Socioeconomic Rights and Directive Principles with a Fundamental Law of Reason in Ghana and Nigeria", Harvard Human Rights Journal 27, (2014), 88 . 
to cover the targeted ESC right. ${ }^{60}$ In the case of Jonah Gbemre v. Shell Petroleum Development Company ${ }^{61}$ the plaintiff, representing a community in the South-South region of Nigeria commenced an action against the respondent whose oil exploration activities and gas flaring infringed on his right to health and right to clean environment of the host community. Hence, the suit sought a declaration and an injunction to restrain the polluting activities of the respondents. The lawsuit was hinged on the relevant sections and provisions of the CFRN and African Charter. The court relied on the provisions of right to life and human dignity under the justiciable $\mathrm{FH}$ rights provisions of the CFRN to grant the prayers of the plaintiff to protect the health and environment of the host community. This amply indicates that Nigerian courts can grant declarative orders to protect the infraction of ESC rights when sought as a subset of FH right. Although the second respondent, in this case, was the Nigerian National Petroleum Corporation, which was in a joint venture with the first respondent, Shell Petroleum company, it would appear that the court is more inclined to activism when the respondent is not the government, especially at the federal and the state levels.

With respect to the coercion of government and its agencies to comply with court orders, particularly in relation ton on-pecuniary orders, no provision in any Nigerian law restrains the court from coercing a government official to perform the order of the court. ${ }^{62}$ The court can summon any official of the government and may initiate contempt proceedings against such official for failure to comply with an order of the court. The challenge is the political will to obey or disregard such order of the court. In most cases, an official of the government who belongs to the same political party with the ruling government may disregard court orders, and nothing would happen because the executive controls the security structure that should execute the order of the court.

Structural interdict mandates the government to rectify the breach of a right under the supervision of the court. This practice would certainly not hold ground in Nigeria because of the principle of functus officio; that is, a court is unable to sit over a suit after it has delivered its judgment. This is captured in the case of F.B.N. Plc v. T.S.A. Ind. Ltd. $^{63}$

\footnotetext{
${ }^{60}$ Nimma Jo-Madugu, "Protection of Socio-economic Rights in Africa: A Comparative Study of the African Union and Selected Countries", Unpublished Master's Thesis, Faculty of Law, Tilburg University, (2017).

${ }^{61}$ AHRLR 151 (Ng HC 2005) (2005).

${ }^{62}$ Section 2 Nigerian Public Officers Protection Act which provides for action against public officers only covers the limitation of time within which an action must be commence against a public officer for acts performed in discharge of official duties. It does not shield the public officer from any court orders on the person of the officer.

${ }^{63} 15$ NWLR [Pt. 1216] (2010) 247 SC.
} 
A court is said to be functus officio in respect of a matter if the court has fulfilled or accomplished its function in respect of that matter and it lacks potency to review, re-open or re-visit the matter. Once a court delivers its judgment on a matter, it cannot revisit or review the said judgment except under certain conditions.

Hence, the rule of judicial precedent effectively makes it impracticable for Nigerian courts to adopt or attempt the structural interdict. An expanded view may be to approach structural interdict from the angle of the Judgment Enforcement Rules ("Enforcement Rules"), subsidiary legislation of the Sheriff and Civil Processes Act. ${ }^{64}$ Here, a litigant may seek an order of the court against the government or its agencies and include an additional prayer for orders compelling the relevant public officer to implement the order against the government, as well as sanctions that would be meted out on the public office where the orders are not complied with. If a litigant successfully secures these orders, and enforcement procedure may be initiated against the public officer under the Enforcement Rules, to enforce those orders directed at the public officer in the judgment of the court. Although this proposal is a long shot in the dark, it has the potential to aid responsiveness of public officers to orders of court and, hence remote supervision of the order by the court.

Concerning the declaration as void, government programs, legislation and policies that infringe on ESC rights, Nigerian courts have held on many occasions that the court would not hesitate to declare void any law or policies of the government that infringes the provision of an extant law. In this instance, any policy of the government that infringes ESC provisions in the African Charter, Universal Basic Education Act, the National Environmental Standards Regulatory and Enforcement Agency Act and the Independent Corrupt Practices Commission (ICPC) Act. In Mangruv. Commissioner of Budge municipality ${ }^{65}$ it was held that "the Directive Principles are required to be implemented by legislation, and so long as there is law carrying out the policy laid down in a Directive Principle, neither the state nor an individual can violate any existing law or legal right under color of following a Directive". ${ }^{66}$ In another case, the Supreme Court of Nigeria was quite emphatic as it posited that the provisions of the African Charter are justiciable. ${ }^{67}$ It was stated that:

\footnotetext{
${ }^{64}$ Afe Babalola (ed.), Enforcement of Judgments (Lagos: AfeBabalola publisher, 2003), 6 \& 7.

6587 CLJ (1951) 361.

${ }^{66}$ G.N. Okeke and C. Okeke, "The Justiciability of the Non-Justiciable Constitutional Policy of Governance in Nigeria",IOSR Journal of Humanities and Social Science 7, No. 1 (2013), https://doi.org/10.9790/0837-0760914.

${ }^{67}$ In the case of Abacha v. Fawehinmi [2000] 6 N.W.L.R Part. 660 at p.249, the Supreme Court placing reliance on the case of, held as follows: "The individual rights contained in the Articles of the African Charter on Human and Peoples Rights are justiciable in Nigerian
} 
The individual rights contained in the Articles of the African Charter on Human and Peoples Rights are justiciable in Nigerian courts. Thus, the Articles of the Charter show that individuals are assured rights which they can seek to protect from being violated and if violated to seek appropriate remedies; and it is in the national courts such protection and remedies can be sought and if the case is established, enforced.

We can therefore safely posit that litigants can take advantage of this judgment to challenge any action successfully, polices or legislation of government and its agencies or private individuals and entities that impinge on ESC right provisions of the African Charter. The High Court and the Court of Appeal are bound to follow the decision of the court above on the principle of stare decisis.

\section{Conclusion}

It thus follows from the decisions of the court above that Nigerian courts can indeed, give impetus to ESC rights and statutes through dynamic approaches to ESC litigation in Nigeria. The challenge seems to be, besides protracted litigation and appeals, in the enforcement of such orders against the government, especially where money, its equivalent or assets is involved. Litigants can explore the option of first crystallizing ESC judicial precedents against public and private entities; and as the volume of such judicial authorities swells, the litigants would have stronger case laws in their arsenal to proceed against government agencies; and the courts would be bound by judicial precedent to issue orders in line with claims founded thereon.

\section{References}

A. Mc Chesney. Promotion, defending Economic, Social and Cultural Rights: A Handbook. Washington D.C. USA: American Association for the Advancement of Science, 2000.

AG of Ondo State v. AG Federation (2002) 9 NWLR, [Pt. 772], at 272.

An-Na'im, Abdullahi. Human Rights under African Constitutions: Realizing the Promise for Ourselves. Philadelphia: University of Pennsylvania Press, 2003.

Archbishop Anthony Okogie v. A.G. Lagos State (1981) 2 NCLR 337.

Babalola, A. Enforcement of Judgments. Lagos: AfeBabalola Publisher, 2003.

courts. Thus, the Articles of the Charter show that individuals are assured rights which they can seek to protect from being violated and if violated to seek appropriate remedies; and it is in the national courts such protection and remedies can be sought and if the case is established, enforced. 
Beetham, D. Democracy and Human Rights. Malden USA: Blackwell Publisher Ltd, 2000.

Chief Gani Fawehinmi v. SaniAbacha (2000) NWLR (Pt. 660) 228.

Christiansen, E.C. "Adjudicating Non-Justiciable Rights: Socio-Economic

Rights and the South African Constitutional Court". Columbia Human Rights L. Rev 321, 38 (2007).

Circle of Rights, "Justiciability of ESC Rights - the Indian Experience" University of Minnesota, Human Rights Resource Centre, available at: http://hrlibrary.umn.edu/edumat/IHRIP/circle/justiciability.htm (retrieved 21 August 2019).

Coomans, F., Hoof, F.V., Arambulo, K., Smith, J. and Toebes, B. The Right to Complain about Economic, Social and Cultural Rights. Utrecht: Netherlands Institute for Human Rights, 1995.

Craven, M. The International Covenant on Economic, Social and Cultural Rights: A perspective on its Development. Oxford: Clarendon Press, 1995.

Ebobrah, S.T. "The Future of Economic, Social and Cultural Rights Litigation in Nigeria." CALS, Review of Nigeria Law and Practice 1, No. 2 (2007).

Eide, A., Krause, C. and Rosas, A. Economic, Social, and Cultural Rights. Kluwer: Martin Nijhoff Publishers, 1995.

F.B.N. Plc v. T.S.A. Ind. Ltd (2010) 15 NWLR [Pt. 1216] 247 SC.

Federal Republic of Nigeria v. Alhaji Mika Anache\& Others (2004) 14 WRN 1.

Francis Coralie Mullin v.The Administrator, Union Territory of Delhi (1981) 2 SCR 516.

Gauri, V. \& Brinks, D.M. Courting Social Justice: Judicial Enforcement of Social and Economic Rights in the Developing World.UK: Cambridge University Press, 2008.

Ghai, Y. \& Cottrell, J. Economic, Social and Cultural Rights in Practice:

The Role of Judges in Implementing Economic, Social and Cultural Rights. London: Interights, 2004.

Government of Republic of South Africa v Irene Grootboom and Others 2001 (1) SA 46 (CC).

Igwe, O. W. "A Legal Assessment of the Positive Duties Imposed by Economic, Social and Cultural Rights in Nigeria." American International Journal of Social Science 3, No. 4 (2014).

International Commission of Jurists. Courts and the Legal Enforcement of Economic, Social and Cultural Rights: Comparative Experiences of Justiciability. Geneva: International Commission of Jurists, 2008.

Jo-Madugu, N. "Protection of Socio-economic Rights in Africa: A Comparative Study of the African Union and Selected Countries." 
Unpublished Master's Thesis, Faculty of Law, Tilburg University, (2017).

Jonah Gbemre v. Shell Petroleum Development Company (2005) AHRLR 151 (Ng HC 2005).

Jordan, Daci. "Justiciability of Economic, Social and Cultural Rights." Academicus-International Scientific Journal 9, (2016), https://doi.org/10.7336/academicus.2014.09.04.

National Coalition for Gay and Lesbian Equality v. Minister of Home Affairs 2000 (2) SA 1 (CC).

Ogugu v. State, (1996) 6 NWLR[Pt. 316] 1.

Okeke, G. N., C. Okeke. "The Justiciability of the Non-Justiciable Constitutional Policy of Governance in Nigeria." IOSR Journal of Humanities and Social Science 7, No. 1 (2013), https://doi.org/10.9790/0837-0760914.

Steiner, H. J. \& Alston, P. International Human Rights in Context: Law, Politics, and Morals. UK: Oxford Fourth Cluster Reader, ERMA, 2003.

Uche, A. D. "Comparative Appraisal of the Protection and Enforcement of Economic, Social and Cultural Rights Under the Law in South Africa, India and Nigeria." Unpublished LL.M Dissertation, Faculty of Law, University of Nigeria, Enugu, (2013). 